\title{
Additional education of children as an innovative resource for the development of regional educational potential
}

\author{
Oksana Pavlova $^{1 *}$, Irina Ivanova $^{2}$, Natalya Chirkova $^{1}$, Yelena Buslayeva $^{2}$, and Irina \\ Burlakova $^{3}$ \\ ${ }^{1}$ Kaluga State University named after K.E. Tsiolkovsky, Institute of Pedagogy, Kaluga, Russia \\ ${ }^{2}$ Kaluga State University named after K.E. Tsiolkovsky, Institute of Social Relations, Kaluga, Russia \\ ${ }^{3}$ Moscow State University of Technology and Management named after K.G. Razumovsky, Institute \\ of Social and Humanitarian Technologies, Moscow, Russia
}

\begin{abstract}
The article describes the Russian experience of building a system of additional education. It is shown that this experience is consistent with world educational practices and has unique features. These features are shown on the example of the Kaluga Region (space-oriented education, support for children's giftedness, and career guidance to the benefit of the region). Additional education of children in Russia is considered a unique educational system. The article presents the global experience of individualoriented educational practice aimed at forming human capital. The authors use statistical data reflecting the work of additional education of children in the region in the context of the Kaluga Region. The novelty of the research is due to the reflective and axiological approach to the organization of pedagogical support of teenagers' self-development in the context of additional education of children as a key element in the formation of human capital. This approach represents a special type of pedagogical interaction. The goal of pedagogical support is searching for their life purpose and implementing the found meanings in the "project of their own life". The article defines the regularities on which the authors' approach is based (a humanistic type of interaction between the teacher and adolescents as accompanist partners; eventfulness of the educational process, which is scoped to the boundaries of the child's life activity in general; building a space for knowing one's selfhood and its implementation by a teenager), as well as basic principles (actualization of reflection, and value attitude of children to their life activity). Pedagogical support of adolescents, based on the ideas of the reflective and value approach, contributes to the development of human capital.
\end{abstract}

Keywords: nonformal education, out-of-school education, personality self-development, reflective and value approach.

* Corresponding author: oksanapav@yandex.ru 


\section{Introduction}

The Kaluga Region is an effective platform to implement various investment projects in the Russian Federation. The key to success is the high educational potential of the region, which is determined by a combination of external (legislative framework) and internal (professional and pedagogical competence of teachers, managerial competence of executives) factors, and includes invariant (resource of educational organizations implementing basic educational programs) and variable (the system of additional education implemented in the formal and informal form) components.

The goal of the research presented in the article is to identify the possibilities of additional education of children (AECh) in the formation of human capital as an innovative resource for the development of the educational potential of the region. The theoretical basis of the study includes the concept of human capital development (V.V. Petty, A. Smith, D. Ricardo, etc.), continuing education (E. Faure), and existential pedagogy (M.I. Rozhkov, etc.) [1]. The novelty of the research consists in developing a "reflective and evaluative approach to the organization of pedagogical support of teenagers' self-development in the context of additional education of children" as a factor of human capital formation.

\section{Methods}

The article considered the AECh in Russia as a unique educational system, presented the global experience of individual-oriented educational practice aimed at forming human capital, as well as used statistical data reflecting individual results of AECh in the region in the context of the Kaluga Region.

\section{Results}

\subsection{Conceptual framework and world practices}

Human capital is a resource that is not standardized and embodied in specific people, reflecting the totality of their abilities, knowledge, skills, and competencies used to meet the diverse needs of a person and society. The most significant age for laying the foundation of intellectual, emotional, and creative capital in children is the age from five to 15 years. To achieve these goals, it is important to use the resources of additional education based on world best practices.

The problem of international comparisons on the concerned issues consists in different approaches to the content of key concepts and terminology used, such as "extracurricular activities, complementary education, additional education, after school education, and outdoor education" [2].

In European practice, the concept of "nonformal education" is used as a resource for the versatile development of pupils, which is becoming of increased interest and accessibility for all segments of the population. Besides, in the practice of additional education in Australia, attention is paid to the social adaptation of pupils, while in the USA - to increase in the pupils' academic merits [2].

In private schools in the UK, the number of additional classes is significantly more than in municipal schools. In the USA, providing additional education services is a direct responsibility of schools. Low cost and even free services are provided by state organizations, such as museums, public ice rinks, sports sections, scientific centers, botanical gardens, etc. $[2]$. 
In general, nonformal education in different countries aims at improving academic results (classes in the STEM subjects and the natural science cycle); developing creative abilities in the artistic and aesthetic sphere (music, fine arts, theater activities); and preserving and strengthening health (sports sections).

Unlike formal education, pupils' achievements in nonformal education cannot be converted; however, studies conducted by authors from different countries indicate that pupils who actively participate in extracurricular activities are more successful and selfsufficient in studying at a university, they are more easily involved in teamwork, and show leadership qualities [3-9].

There is an understanding that foreign countries and Russia have similar problems in assessing the quality of nonformal education and converting its results [10]. The importance of the experience gained by children is recognized not only in the aspect of further education at the university but also for the formation of human capital in general.

\subsection{Additional education of children in Russia}

Historical and theoretical analysis of the formation of the AECh in Russia allows tracing the development of this education system, which began to develop in the late $19^{\text {th }}$ century as outof-school education, while since 1917 - as out-of-school upbringing. The wording of "additional education of children" was coined in the education sector in 1992.

Currently, the system of additional education in the Russian Federation includes an extensive and developing network of organizations and corresponding implemented multidirectional programs. The development trajectory is set by various regulatory acts [1113]. The Law on Education [11] notes that educational programs can have both general development and pre-professional character. The list of areas is quite broad. The Concept [12] sets out the basic principles and targets of the AECh. The national project [13] lists the immediate tasks involving solving the problems of early career guidance, updating the resource support for physical culture and sports; using the potential of schools to implement multidirectional additional education services (about $6 \%$ of children); creating centers that implement pre-school programs at universities, and expanding the network of Quantorium children's technoparks.

\subsection{Regional specifics of the system}

The development of the AECh system in the region can be monitored through indicators such as the number of organizations involved, the number of teachers and their professional level, the number of children who consume services, the number of educational programs, etc. (Table 1).

Table 1. Indicators of the AECh system in the Kaluga Region for the 2019-2020 academic year [14].

\begin{tabular}{|c|c|c|c|c|c|}
\hline No & Area & $\begin{array}{c}\text { Number of } \\
\text { programs }\end{array}$ & $\begin{array}{c}\text { Number } \\
\text { of } \\
\text { associations }\end{array}$ & $\begin{array}{c}\text { Number } \\
\text { of } \\
\text { pupils }\end{array}$ & $\begin{array}{c}\text { The number of } \\
\text { involved AECh } \\
\text { organizations }\end{array}$ \\
\hline 1. & Artistic & 485 & 391 & 17,538 & 26 \\
\hline 2. & Social and pedagogical & 276 & 251 & 10,353 & 25 \\
\hline 3. & Technical & 134 & 111 & 3,334 & 21 \\
\hline 4. & Physical culture and & 57 & 45 & 2,264 & 14 \\
\hline 5. & Tourist and local history & 45 & 44 & 1,488 & 19 \\
\hline & Total: & $\mathbf{9 9 7}$ & $\mathbf{8 4 2}$ & $\mathbf{3 4 , 9 7 7}$ & $\mathbf{2 6}$ \\
\hline
\end{tabular}


Thus, $70 \%$ of teachers of the AECh system work at a high professional level. The level of involvement among children aged 5-18 years amounts to $61.7 \%$ (annual growth is $14.9 \%$, while target value is $71 \%$ ) [15].

Regional value orientations are:

1. Offering space-oriented education associated with the name of K. Tsiolkovsky, which is reflected in the names of educational organizations and the content of educational work (Galaxy Children and Youth Center for Space Education and the Constellation Center for the Development of Creativity of Children and Youth of the city of Kaluga).

2. Supporting children's giftedness, implemented through the identification and pedagogical support of gifted children of all ages; their involvement in competitive and Olympiad activities.

3. Providing career guidance with a regional bias, implemented through the involvement of employees of regional scientific and technical laboratories in the work of additional education centers and the inclusion of children in professionally-oriented tour programs.

\section{Authors' approach to additional education of children}

When developing this approach, the authors relied on the theoretical analysis of pedagogical literature, as well as real practices of AECh and training of teachers for this sector of education.

As a unique type of education, the following characteristics of the AECh in Russia were identified as fundamental units: choosing voluntarily educational services (teacher, program orientation, and pace of its mastering); constructing the educational process using an eventbased method of interaction; focusing on the child's self-development and creativity; providing flexibility in embedding educational trajectories; ensuring the ability to build an individual field of self-actualization for each child [16-19].

The authors' "reflective and value approach to pedagogical support of self-development of adolescents" (authored by I.V. Ivanova, and supervised by the head of the scientific school Prof. M.I. Rozhkov) can become the approach that unites all these specific features. This approach assumes a special type of interaction between teenagers and the teacher. The teacher acts as an accompanist partner, encouraging the accompanied teenager to reveal the meaning of his own life, building value orientations, namely, life-purpose orientations.

The accompanist teacher builds the educational process in such a way as to form a teenager's readiness to build and implement his own self-development project - the project of his own life.

Procedural aspects of the implementation of the declared approach are manifested in several patterns: a humanistic type of interaction between the teacher and teenagers as accompanist partners, eventfulness of the educational process scoping to the limits of child's life in general, and building a space for knowledge of his selfhood and its actualization by a teenager. The leading principles of the considered support are the actualization of reflection, the value attitude of teenagers to their life, thought creation and its real implementation.

The implementation of the proposed approach is addressed to teachers of AECh since it is the AECh system that has broad educational and developmental resources.

\section{Conclusion}

Additional education is a pedagogical tool that fully corresponds to contemporary educational values and tasks. The AECh system in Russia, on the one hand, is consistent with global development trends of educational systems and, on the other hand, has unique features predetermined by national and regional peculiarities. 
In the Kaluga Region, considerable attention is paid to space-oriented education, early support for giftedness, and professionalization to the benefit of the region. The scientific approaches developed in the region to the organization of pedagogical support of children (reflective and value approach) meet the imperative of the time, as well as absorb all the fundamental principles of humane and existential pedagogy. Awareness in the construction of children's plans for their own development, based on the system of traditional values, accumulates the potential of individuals. This results in the formation of human capital in new generations, which leads to the next round of the educational potential development of the region.

\section{Acknowledgments}

The study was carried out with the financial support of the Russian Foundation for Basic Research in the framework of scientific project No. 20-013-00616.

\section{References}

1. M.I. Rozhkov, Conceptual Ideas, Works, Students (Yaroslavl, Yaroslavl State Pedagogical University named after K.D. Ushinsky, 2016)

2. N.M. Zhulyabina, Additional education of children abroad: understanding, politics, regulation. Series Modern Education Analytics, 9(17) (NRU HSE, Moscow, 2017). https://ioe.hse.ru/data/2018/02/07/1162172500/\%D0\%A1\%D0\%90\%D0\%9E_9\%2817 $\% 29 \_\%$ D1\%8D $\%$ D0\%BB $\%$ D0\%B5\%D0\%BA\%D1\%82\%D1\%80\%D0\%BE $\%$ D0 $\%$ B D\% $\overline{\mathrm{D} 0} \% \mathrm{BD} \% \mathrm{D} 1 \% 8 \mathrm{~B} \% \mathrm{D} 0 \% \mathrm{~B} 9 . \mathrm{pdf}$

3. N.U. Saqib, M. Abdul Raheem, M. Iqbal, M. Salman, T. Shahzad, Effects of Extracurricular Activities on Students (Department of Electrical Engineering College of Electrical and Mechanical Engineering, National University of Sciences and Technology, January 2018)

4. R. Freeman, The Relationship Between Extracurricular Activities and Academic Achievement. Submitted in partial fulfillment of the requirements of Doctor of Education at National Louis University National College of Education, National Louis University, Chicago (2017). https://digitalcommons.nl.edu/diss/245

5. T. Braden, The BYU Undergraduate Journal in Psychology, 12(2), Art. 14 (2017). https://scholarsarchive.byu.edu/intuition/vol12/iss2/14

6. A. Tansel, International Perspectives on Education and Societ, 22, 23-66 (2013). https://doi.org/10.2139/ssrn.2331236

7. A. Dyson, K. Kerr, Journal for educational research online 6(3), 76-94 (2014). https://www.pedocs.de/volltexte/2014/9688/pdf/JERO_2014_3_Dyson_Kerr_Out_of_s chool_time.pdf

8. A. Antovska, B. Kostov, International Journal of Cognitive Research in Science, Engineering and Education, 4(1), 49-54 (2016). https://doi.org/10.5937/IJCRSEE1601049A

9. S.H. Bae, J.L. Mahoney, S. Maschke, L. Stecher, Developments in Research on Extended Education: Perspectives on Extracurricular Activities, After-School Programs, and All-Day Schools (Barbara Budrich Publishers, Berlin, 2019)

10. I.I. Burlakova, Akademicheskiy vestnik, 1(31), 115-120 (2015) 
11. Federal Law "On Education in the Russian Federation” No. 273-FZ of December 29, 2012 (as amended), http://publication.pravo.gov.ru/Document/View/0001201212300007

12. Order of the Government of the Russian Federation "On approval of the Concept for the development of additional education for children" No. 1726 dated September 4, 2014. http://static.government.ru/media/files/ipA1NW42XOA.pdf

13. National Project "Education" (Ministry of Education of the Russian Federation, 2018). https://edu.gov.ru/national-project

14. N.S. Pavlyushina, I.A. Khalturina, O.K. Payyer, Ye.V. Palchenko, Software analysis of continuing education organizations in the Kaluga region for 2019-2020 academic year (Kaluga, 2019). http://ocdod40.ru/wpcontent/uploads/2019/12/Analiz_programmnogo_obespechenia_2019-2020.pdf

15. Kaluga education on the eve of the 2019/20 academic year. Public report on the state and performance of the education system of the municipal entity "City of Kaluga" for the 2018/19 academic year (Education Department of the city of Kaluga, Kaluga, 2019). https://admoblkaluga.ru/upload/minobr/2019/08/9/Doklad.pdf

16. A.G. Asmolov, Privolzhskiy pedagogicheskiy poisk, 1(23), 13-19 (2018)

17. L.G. Loginova, Vospitaniye shkolnikov, 1, 58-63, (2020)

18. O.A. Pavlova, N.I. Chirkova, Humanization of Education, 5, 88-93 (2018)

19. I.V. Ivanova, Russian Education \& Society, 58(11), 718-731 (2016).

https://doi.org/10.1080/10609393.2017.1342195 